\title{
Top Management Commitment and Diversity Challenges in Telecom Sector
}

\author{
Ursil Majid Makhdoomi \\ Research Scholar, Department of Management Studies, \\ Central University of Kashmir, Jammu and Kashmir, India \\ E-Mail: ursilmakhdoomi@gmail.com
}

\begin{abstract}
The organisations in today's world need to recognize the value of having a diverse workforce as all the top companies around the world are composed of a variety of people from different cultures, races, castes, ethnicities etc. The support of top management is not only important in managing the diverse workforce but also in implementing the diversity strategies and policies, as diversity strategies can be expensive and the budgetary constraints can make it difficult to implement these strategies in the absence of a committed top management (Laudicina, 1995). The study analyzes analyze the commitment of top management towards diversity management and also various challenges to diversity. The sample of 382 from two telecom organizations was used. Results reveal that top management commitment is significant in both organisations but MTNL shows higher commitment as compared to Airtel and diversity challenges are equally significant in both MTNL and Airtel. The major barriers to diversity faced by MTNL are minimal support of the management and certain external influences while as Airtel faces the major barrier of the dearth of proper expertise to manage diversity.
\end{abstract}

Keywords: Workforce diversity, Top management commitment, diversity challenges

\section{INTRODUCTION}

The organisations in today's world need to recognize the value of having a diverse workforce as all the top companies around the world are composed of a variety of people from different cultures, races, castes, ethnicities etc. These people have different sets of skills, talents, attitudes, knowledge and different ways to handling different problems, thus providing an organisation numerous ways to tackle the same problem. Thus every organisation whether public or private, in order to improve efficiency, creativity and become open to change need to have a diverse workforce.

For corporate success it is essential to have a diverse workforce (Joplin \& Daus, 1997). Workforce diversity can help in the success of organisations if their organisational environment could attract people from different markets (Sania et. al 2013). If an organisation focuses on being diverse, it has to foster such an organisational culture where each and every employee can pursue his aspirations without being inhibited by gender, race, culture, language, nationality, caste, color etc (Bryan,1999).

\section{LITERATURE REVIEW}

\section{A. Top Management Commitment}

Research has shown the support of diversity strategies and top management's commitment towards diversity efforts is important rather crucial for the organisation's efforts (Rynes \& Rosen, 1995). The support of top management is not only important in managing the diverse workforce but also in implementing the diversity strategies and policies, as diversity strategies can be expensive and the budgetary constraints can make it difficult to implement these strategies in the absence of a committed top management (Laudicina, 1995). Top management needs to be receptive towards diversity and have a vision and should be committed to ensuring that the organisation unbiased diversity policies and strategies which will help the organisation to completely make use of the diverse knowledge, talents and skills of the workforce (Cox, 2002). The commitment of the leaders and the revision of policies of the organisation so that they support diversity are of major importance for building diversity. Any diversity initiatives won't be effective without the support of the top management (Carnevale \& Stone, 1994).

Organisations are making use of accountability in order to make leaders committed towards diversity (Carnevale \& Stone, 1994). Some organisations use appraisals, bonuses and compensation for the achievement of their diversity goals (Caudron, 1992). Those leaders who are capable of developing diversity and are able to benefit from it are essential to the success of organisations (Morrison, 1992). And in order to cope with the changing organisational culture, leaders need to play a visible and dominant role from the beginning to acknowledge the value and promote diversity and to communicate this throughout the organisation (Loden \& Rosener. 1991). The lack of an effective management results in fragmented diversity efforts which lack coherence, thus the cohesion of diversity efforts have to be in the hands of capable leaders who would be able to build relationships across each and every level of the organisation (Tomervik, 1995).

Human resource directors face major challenges in developing diversity in the organisations. The changes required to develop diversity are difficult (Zane, 2002). In order to meet these challenges it takes skilled training and 
organisational knowledge and also shared understanding that diversity management is not a problem but a process and top management commitment (Zane, 2002). In order to sustain lasting diversity changes, both leadership commitment and strategic planning are required (Howland, 2001). Zane, 2002, in his article, described that a sustained commitment and involvement in different communities within the organisation by the CEO leads to employees who take responsibility for defining and implementing positive changes which support diversity. Thus for proper valuation and management of diversity, the top management of the organisation needs to be committed to it. For the diversity to give positive results the management has to get directly involved in planning, implementing and holding employees accountable for the diversity strategies.

\section{DIVERSITY CHALLENGES}

Many studies have found that groups in an organisation that is diverse do not automatically perform better as they do not connect effectively with their groups and they do not feel committed to their organisations (Millikin \& Martins 1996). Diversity can thus create problems for the organisation (Miller \& Rowney, 1999). Various researchers have documented two major reasons which make the implementation of diversity in the organisations difficult (Bassett-Jones, 2005; Cox, 2001). The first reason is that employees prefer to work in groups that are homogenous and the second reason is the employees' resistance to change.

Harold Andrew Patrick and Vincent Raj Kumar (2012) examined the barriers of a diverse workplace. The study was based on a survey of 300 IT employees selected from 15 IT companies of India. The study revealed that the most common barrier to accepting diversity was found to be discrimination, prejudice and ethnocentrism. And the less common were blaming the victim, harassment, stereotypes and lastly backlash. Another study focusing on barriers faced by employees in IT sectors of India for accepting workforce diversity by Rajesh Vaidya, Vinod Wanjari, Nitin Shirigirwar in 2013 also revealed that the most frequently encountered barrier in Indian organisations was discrimination which was followed by prejudice and ethnocentrism.

Poornima Tejpal and Vikas Nath (2013) aimed at examining the potential barriers of diversity. The study reviewed the diversity practices of organisations which included Infosys, Accenture and IBM. The paper suggested ways, to make the workplace inclusive by recruiting diverse talent, start support groups, training and mentoring, implementing a diversity policy in the organisation and hiring a diversity consultant. The study revealed that an incompetent organisational strategy leads to reduced employee morale and increase conflicts among employees.

Some of the common barriers to diversity management as explained by Kreitner, 2001 are:
1. The existence of an unsupportive working environment where diverse employees are excluded from various social activities which prevent them from networking with other employees.

2. People are afraid of bias and discrimination in organisations where people of different nationalities work due to which they do not apply to such organisations.

3. Employees resist changes as they think it will bring failure, mistrust and peer pressure.

4. Diversity is not viewed as a priority that would contribution to the success of an organisation.

5. Women most likely face the challenge of balancing between career and family.

6. Negative behaviours and attitudes are also challenges to organisational diversity as they damage relationships among employees, harm employee morale and affect work productivity (Esty et al., 1995).

\section{OBJECTIVES}

1. To analyze the commitment of top management towards diversity management.

2. To study various challenges, if any in the management of diversity.

\section{HYPOTHESES}

$\mathrm{H}_{01}$ : Top Management Commitment towards diversity is insignificant within the organisation.

$\mathrm{H}_{02}$ : Diversity Challenges within the organisation are insignificant.

\section{METHODOLOGY}

The region of the study was Delhi/NCR, it was chosen for its wide diversity of people. Empirical analysis was employed and data was gathered through a structured questionnaire. The questionnaire included demographic data and questions related to various strategies and status of diversity. The study was conducted on telecom organizations. The sample was drawn from one public and one private telecom company in Delhi/NCR, which included employees from top management. Both primary and secondary data was examined for the study. The determination of sample size was done through a sampling technique called random sampling. The data for the study was acquired from 60 respondents 30 from each organization.

\section{A. $H_{01}$ : Top Management Commitment towards diversity is insignificant within the organisation}

One sample $t$ test was performed with reference of mean score 3 which is the mid-point of the scale. The results are shown in the below table which reveals top management commitment in public organisation with the mean score of 3.56 which is more than the referenced point indicating the mean score is significantly high $(\mathrm{t}=-4.802, \mathrm{p}=.000)$, thus 
the top management of sampled organisation is committed towards diversity while as in case of private organisation the mean score is 3.48 which is also higher than the referenced point $(\mathrm{t}=4.160, \mathrm{p}=.000)$.In both the organisations the top management has being found to be committed towards the incorporation and management of diversity as both reveal a higher mean score, with public organisation showing a little higher commitment as compared to the private organisation.

TABle I One SAMPle StATistics- Top MANAGEMENT COMMITMENT

\begin{tabular}{|c|c|c|c|c|}
\hline \multicolumn{2}{|c|}{ Nature } & N & Mean & Std. Deviation \\
\hline Public & Tmc & 30 & 3.5667 & .64639 \\
\hline Private & Tmc & 30 & 3.4833 & .63631 \\
\hline
\end{tabular}

TABLE II ONE SAMPle TEST- Top MANAGEMENT COMMITMENT

\begin{tabular}{|c|c|c|c|c|c|}
\hline \multirow{2}{*}{ Nature } & \multicolumn{4}{c|}{ Test Value = 3 } \\
\cline { 3 - 6 } & T & Df & Sig. (2-tailed) & Mean Difference \\
\hline Public & Tmc & 4.802 & 29 & .000 & .56667 \\
\hline Private & Tmc & 4.160 & 29 & .000 & .48333 \\
\hline
\end{tabular}

In both the companies top management is being held accountable for the management of diversity as shown in the table below.

TABLE III PERCENTAge ACCOUNTABILITY

\begin{tabular}{|c|c|c|c|c|c|c|}
\hline \multicolumn{3}{|c|}{ Nature } & Frequency & Percent & Valid Percent & Cumulative Percent \\
\hline \multirow{3}{*}{ Public } & \multirow{3}{*}{ Valid } & Yes & 28 & 93.3 & 93.3 & 93.3 \\
\cline { 3 - 7 } & & No & 2 & 6.7 & 6.7 & 100.0 \\
\cline { 3 - 7 } & & Total & 30 & 100.0 & 100.0 & \\
\hline Private & Valid & Yes & 30 & 100.0 & 100.0 & 100.0 \\
\hline
\end{tabular}

B. $H_{02}$ : Diversity Challenges within the organisation are insignificant

TABLE IV ONE-SAMPLE STATISTICS-DIVERSITY CHALLENGES

\begin{tabular}{|c|c|c|c|c|}
\hline \multicolumn{2}{|c|}{ Nature } & N & Mean & Std. Deviation \\
\hline Public & DCH & 30 & 3.5167 & .79190 \\
\hline Private & DCH & 30 & 3.5833 & .57361 \\
\hline
\end{tabular}

TABLE V ONE-SAMPLE TEST-DiVERSiTy ChALLENGES

\begin{tabular}{|c|c|c|c|c|c|}
\hline \multirow{2}{*}{ Nature } & \multicolumn{4}{c|}{ Test Value = 3 } \\
\cline { 3 - 6 } \multicolumn{2}{|c|}{} & T & Df & Sig. (2-tailed) & Mean Difference \\
\hline Public & DB & 3.574 & 29 & .001 & .51667 \\
\hline Private & DB & 5.570 & 29 & .000 & .58333 \\
\hline
\end{tabular}

One sample $\mathrm{t}$ test was performed with reference of mean score 3 which is the midpoint of the scale. The results are shown in the above table which reveals diversity challenges or barriers in public organisation with the mean score of 3.51 which is more than the referenced point indicating the mean score is significantly high $(t=3.574, p=.001)$, while as in case of private organisation the mean score is 3.58 which is also higher than the referenced point $(\mathrm{t}=5.570, \mathrm{p}=$ .000). Thus diversity challenges exist in both the organisations.
In order to assess the challenges or the barriers individually and supplement the results the mean scores of the items were calculated. All the listed barriers show higher mean scores but the major challenges to diversity in case of MTNL are Limited financial resources and external environmental influences while as in case of Airtel is dearth of specific expertise and skills as they show higher mean score. 
TABLE Vi MEAN SCORE-DivERSITY CHALLENGES

\begin{tabular}{|c|c|c|c|c|c|c|c|c|c|c|c|}
\hline \multirow{2}{*}{$\begin{array}{l}\text { S. } \\
\text { No. }\end{array}$} & \multirow[b]{2}{*}{ Diversity Barriers } & \multicolumn{5}{|c|}{ Public } & \multicolumn{5}{|c|}{ Private } \\
\hline & & $\mathbf{N}$ & Minimum & Maximum & Mean & $\begin{array}{c}\text { Std. } \\
\text { Deviation }\end{array}$ & $\mathbf{N}$ & Minimum & Maximum & Mean & $\begin{array}{c}\text { Std. } \\
\text { Deviation }\end{array}$ \\
\hline 1 & $\begin{array}{l}\text { Employees resistance } \\
\text { to change }\end{array}$ & 30 & 2 & 5 & 3.57 & .898 & 30 & 3 & 5 & 3.60 & .724 \\
\hline 2 & $\begin{array}{l}\text { Miscommunication } \\
\text { among various } \\
\text { employees of diverse } \\
\text { groups }\end{array}$ & 30 & 1 & 5 & 3.43 & .971 & 30 & 3 & 5 & 3.57 & .728 \\
\hline 3 & $\begin{array}{l}\text { Limited financial } \\
\text { resources }\end{array}$ & 30 & 1 & 5 & 3.37 & .928 & 30 & 3 & 5 & 3.43 & .568 \\
\hline 4 & $\begin{array}{l}\text { Minimal support of } \\
\text { top management }\end{array}$ & 30 & 2 & 5 & 3.60 & .855 & 30 & 3 & 5 & 3.60 & .675 \\
\hline 5 & $\begin{array}{l}\text { Dearth of specific } \\
\text { expertise/skills }\end{array}$ & 30 & 2 & 5 & 3.53 & .860 & 30 & 3 & 5 & 3.67 & .711 \\
\hline 6 & $\begin{array}{l}\text { External } \\
\text { environmental } \\
\text { influences }\end{array}$ & 30 & 1 & 5 & 3.60 & 1.102 & 30 & 3 & 5 & 3.63 & .718 \\
\hline
\end{tabular}

\section{FINDINGS}

1. Top management commitment is significant in both organisations but MTNL shows higher commitment as compared to Airtel.

2. Diversity challenges are equally significant in both MTNL and Airtel. The major barriers to diversity faced by MTNL are minimal support of the management and certain external influences while as Airtel faces the major barrier of the dearth of proper expertise to manage diversity.

\section{CONCLUSION}

The public and private telecom companies both demonstrate commitment towards diversity. The more the top management shows commitment towards the effective management of diversity the more will be the contributions of diversity in the organisation. There have been many challenges faced by both public and private organisations. The major challenges included employee's resistance to change, miscommunication among the employees from different backgrounds, religions, languages, gender, age, education, experience etc. There is also a problem of limited financial resources faced by public organisations. Another challenge faced by organisations is the dearth of specific expertise and skills. Certain external influences also have become a challenge for the organisations for managing diversity. In case of the public organisation the major challenge found was the minimal support of the top management and effect of certain external influences while as in case of private organisation the major challenge was the dearth of specific skills and expertise in managing the workforce diversity.

\section{REFERENCES}

[1] N. Bassett-Jones, "The paradox of diversity management, creativity and innovation”, Creativity \& Innovation Management, Vol. 14, pp. 169-175, 2005.

[2] J. Bryan, "The diversity imperative", Executive Excellence, Vol. 6, 1999.

[3] A. P. Carnevale and S. C.Stone, "Diversity beyond the golden rule", Training \& Development, Vol. 49, No. 10, pp. 22-39, 1994.
[4] S. Caudron, "U.S. West finds strength in diversity" Personnel Journal, Vol. 71, No. 3, 40-44, 1992.

[5] T. Cox, "Taking diversity to the next level”, Executive Excellence, Vol. 19, No. 4, pp.19-19, 2002.

[6] K. C. Esty, R. Griffin and M. S. Hirsch, Workplace diversity, Adams Media, 1995.

[7] J. S. Howland, "Challenges of working in a multicultural environment”, Journal of library administration, Vol. 33, No. 1-2, pp.105-123,2001.

[8] J. R. Joplin and C. S. Daus, "Challenges of leading a diverse workforce”, The Academy of Management Executive, Vol. 11, No. 3, 32-47, 1997.

[9] R Kreitner and A Kinicki, “Organisational Behaviour" 5th Edition, New York: McGraw-Hill, 2001.

[10] E. V. Laudicina, "Managing workforce diversity in government: An initial assessment”, Public Administration Quarterly, pp.170-192, 1995.

[11] M. Loden and J. B.Rosener, "Workforce America!: Managing employee diversity as a vital resource”, McGraw-Hill, 1991.

[12] G. E. Miller and J. I. Rowney, "Workplace diversity management in a multicultural society", Women in Management Review, Vol. 14, No. 8, pp. 307-315, 1999.

[13] F. J.Milliken and L. L.Martins, "Searching for common threads: Understanding the multiple effects of diversity in organisational groups”, Academy of Management Review, Vol. 21, No. 2, pp. 402433, 1996.

[14] A. M.Morrison, "The New Leaders: Guidelines on Leadership Diversity in America. Jossey-Bass Management Series”, Jossey-Bass, Inc., Publishers, 350 Sansome Street, San Francisco, CA 941041992.

[15] H. A.Patrick and V. R. Kumar, "Managing workplace diversity: Issues and challenges", Sage Open, Vol. 2, No. 2, 2158244012444615, 2012

[16] S. Rynes and B. Rosen, "A field survey of factors affecting the adoption and perceived success of diversity training”, Personnel Psychology, Vol. 48, No. 2, pp.247-270,1995.

[17] U. Sania, K. Kalpina and H. Javed, "Diversity, Employee Morale and Customer Satisfaction: The Three Musketeers", Journal of Economics, Business and Management, Vol. 3, No. 1, pp.11-18, 2015.

[18] P. Tejpal and V.Nath, "Diversity at Workplace: Creating an Inclusive Culture”, Anveshanam: The Journal of Management, Vol. 2, pp.3550, 2013.

[19] K. Tomervik, "Workforce diversity in Fortune 500 corporations headquartered in Minnesota: Concepts and practices", Unpublished doctoral dissertation, University of Minnesota, St. Paul, 1994.

[20] R. Vaidya, V. Wanjari and N. Shirigirwar, "An Empirical Study of Managing Diversity at Workplace with special reference to Indian organization”, ASM's International E-Journal of Ongoing Research in Management and IT, pp. 1-9, 2013.

[21] N.C. Zane, "The glass ceiling is the floor my boss walks on: Leadership challenges in managing diversity", The Journal of Applied Behavioral Science, Vol. 38, pp. 334-354, 2002. 